down to a specification of the skin sutures, seems unnecessary. The section dealing with the important subject of common duct strictures describes well the operative methods but does not discuss the prognosis nor the significance of cholangitis in this condition.

This is a useful book which is well worth reading by all who practise abdominal surgery. It is, furthermore, readable. It is a pity that there are a few slightly inadequate sections in a book of this price but these are to some extent compensated by the excellent bibliography.

\section{A MANUAL OF PRACTICAL OBSTETRICS}

By the late O'Donel Browne, M.B., M.A.O., M.A., Litt.D., F.R.C.P.I., F.R.C.O.G. Edited and largely rewritten by J. G. GallaGHER, M.D., M.A.O., F.R.C.P.I., M.R.C.O.G. Third Edition. Pp. viii +265 , with 203 illustrations. Bristol: John Wright \& Sons Ltd. I956. 37s. 6d.

This book falls between several stools. It tries to be a book on practical obstetrics and at the same time to enter into many theoretical considerations.

As a consequence, it loses its value as a work of practical advice or as a textbook of obstetrics. In addition, there are a number of lapses. For instance, the writer appears to recommend that the second stage of labour in a primigravida should be allowed to last three hours before interference is indicated and he thinks that the head is not likely to have appeared between the labia for two hours.

He recommends Credé's technique in the third stage of labour which most authorities now warn against because of the likelihood of producing shock.

Drawings are shown of how to plug the uterus, which again should not be taught too facilely. As chapter succeeds chapter, one can find similar criticisms. In fact, by and large, I do not think this book is to be recommended.

\section{E.E.P.}

\section{ANATOMICAL TECHNIQUES}

By D. H. Tompsett, B.Sc., Ph.D. Pp. xvi +240 , with 83 illustrations. Edinburgh: E. \& S. Livingstone Ltd. 1956. 35 s.

This book contains an account of many of the more recent techniques which are used for the preparation and mounting of macroscopic anatomical specimens for a museum. The principal techniques described are those of dissection, the making of perspex containers, and the preparation of casts in synthetic resins of blood vessels, the ventricles of the brain and other cavities. There is a short but useful chapter on the illustration of anatomical dissections, and Miss Jessie Dobson provides an interesting historical introduction. Although designed for anatomical specimens, most of the techniques described would be of equal value in the preparation and mounting of pathological material.

The methods are those which Dr. Tompsett has developed in recent years at the Royal College of Surgeons, and those who have seen the very beautiful and instructive specimens which have been added to the anatomical collection at the College will be in no doubt about their value and effectiveness. They are described in great detail, with no attempt to conceal the difficulties, or to underestimate the patience and skill which are necessary to produce really first-class results. More important perhaps is the fact that there is no concealment of the many small but essential steps of a practical nature which must be followed meticulously if success is to be achieved. A most useful feature, often lacking in books of this kind, is a list of sources from which all the instruments, materials or apparatus used, can be obtained.

The book is a notable addition to the literature of craftsmanship; it will be invaluable to museum curators and technicans, and of considerable general interest to anyone who uses an anatomical or pathological museum.

\section{MODERN VIEWS ON THE SECRETION OF URINE}

The Cushny Memorial Lectures

Edited by F. R. Winton, M.A., M.D., D.Sc. Pp. 292, with ro illustrations. London: J. \&, A. Churchill. I956. 30s.

To commemorate the work of Prof. A. R. Cushny (who held the Chair of Pharmacology at University College, London, from 1905 to 1918) ten lectures were delivered there in 1955 by distinguished speakers. Of these, eight are either still working in the College or in U.C.H., or have done so in the past.

This book, therefore, very largely represents an indirect tribute to a great man by workers both in the field and in the school in which his leadership was inspiring. The lectures deal with both physiological and clinical aspects of renal function. Very complete reviews of recent work on the mechanism of normal urine formation are given by Dicker, Eggleton and Pickford. Prof. Winton contributes an important chapter on Pressures and Flows in the Kidney, and L. E. Bayliss describes Secretion. (This would have interested Cushny most of all !) Clinicians will find the very able reviews of Nabarro (The influence of the adrenal cortex) and of Prof. Rosenheim (Functional aspects of Renal Failure) most valuable. A very interesting chapter by Harris deals with Genetic aspects of Tubular Function-much of this work has come from other workers at U.C.H., notably Prof. Dent. (Surely congenital pitressin-sensitive diabetes insipidus is rare enough to merit a reference !) Prof. McCance and E. M. Widdowson (Metabolism and Renal Function in the First Two Days of Life) and Prof. Bull (Osmotic Diuresis 
in Acute Tubular Failure) are the only contributors to this excellent book who stand outside the distinguished school where Cushny taught.

\section{NEURAL CONTROL OF THE PITUITARY GLAND}

By G. W. Harris, F.R.S., Sc.D., M.D. Pp. ix + 298, with 53 illustrations. London: Edward Arnold Ltd. I 955 . 30s.

The most casual glance through the pages of this book cannot fail to impress. Here is a scholarly work which presents an up-to-date account of the present knowledge about the Pituitary Gland and its anatomical and functional relationship to the Central Nervous System. The arguments brought forward are clearly stated and answered and flow logically on to the next, whilst much of the author's own experimental work is modestly woven into the fabric of newer knowledge.

From all aspects, comparative morphology and physiology, clinical and experimental endocrinology, this is a book of great importance. A random sample shows an account of the transplantation experiments which lead to the recognition of the hypophysical portal system on the one hand, and on the other a delightfully lucid account of observations on the ACTH, Thyrotrophic and Gonadotrophic hormone mechanisms and their clinical implications.

One need say no more than that this book is most strongly recommended.

B.J.H.

\section{THE BLOOD-BRAIN BARRIER}

\section{With special regard to the use of radioactive isotopes}

By Louis Bakay, M.D., F.A.C.S. Pp. xii + I54, with 32 illustrations. Oxford: Blackwell Scientific Publications. 1956. £2.

This is the latest of a line of monographs produced from a well-known publishing house. Perhaps the title of the book will tend to limit its circulation to a relatively small group of scientific readers, but when one examines the subject matter one finds that the author has touched on many matters of importance to clinical neurology.

Essentially this is an account of original work by the author in using radio-isotopic methods for the elucidation of the functional properties of the Blood-Brain Barrier, a physiological structure whose importance has long been clear but whose secrets are only just beginning to be unravelled. Although perhaps clear to those working in this field, it is unfortunate that for those unfamiliar with it the wealth of detail enclosed in these pages tends to obscure the chemico-physiological principles which have emerged as a result of the studies. Nevertheless this is clearly a book of considerable importance and should be read.

\section{POSTURAL DRAINAGE}

By E. Winifred Thacker, M.C.S.P. Pp. viii + 56, with 37 illustrations. London: Lloyd-Luke Ltd. I 956. Price not stated.

The details of physio-therapeutic methods are unknown to most doctors. This small, but excellent, book should be of great value to all who treat patients who might benefit from postural lung drainage. It should enable them to order this treatment more intelligently and supervise its application.

\section{BORDERLANDS OF THE NORMAL AND EARLY PATHOLOGIC IN SKELETAL ROENTGENOLOGY}

By Prof. Dr. Alban Köhler. Revised by Dr. E:

A. ZIMMER, English Translation edited by JAMES

T. CASE, M.D., D.M.R.E. Tenth Edition. Pp. xiv +723 , with 1,300 illustrations. New Yorlo and London: Grune and Stratton, Inc. I956 $\$ 24,5$.

Prof. Köhler s great book was first translatec into English in 1928, and a further edition was translated in 1935. The present volume is a translation of the tenth German edition, made almost simultaneously with the preparation of the latter. It contains a much larger Bibliography than the parent volume (a tribute to the pains taken by the translator and a reflection, perhaps, of that unhappy period of isolation from which German medicine seems to be emerging only very slowly).

This book must prove indispensable to every department of radiology. It is encyclopaedic in scope, describing and illustrating an enormous number of minor variations and early pathological deviations from the normal. The translation is clear and lucid. There are thousands of references and a full index. The standard of printing (which is German) is very high indeed and the illustrations are very beautifully and clearly reproduced. The translator is to be congratulated on a very high standard of proofreading, so often faulty in a book printed on the Continent. 